\title{
Application of Molecular Pathology in Endocrine Pathology
}

\author{
Ebru SERINSOZ LINKE', Gaye GÜLER TEZEL² \\ Department of Pathology, ${ }^{2}$ Mersin University Faculty of Medicine, MERSIN, TURKEY, ${ }^{2}$ Hacettepe University Faculty of Medicine, ANKARA, TURKEY
}

\begin{abstract}
Rapid growth in knowledge of cell and molecular biology led to the increased usage of molecular techniques in anatomical pathology. This is also due to the advances achieved in the techniques introduced in the last few years which are less laborious as compared to the techniques used at the beginning of the "molecular era". The initial assays were also very expensive and were not performed except for selected centers. Moreover, the clinicians were not sure how to make use of the accumulating molecular information. That situation has also changed and molecular techniques are being performed in a wide variety of medical settings which also has a reflection on the endocrine system pathology among other organ systems. This review will provide an update of genetic changes observed in different endocrine system pathologies and their diagnostic, therapeutic and prognostic values.
\end{abstract}

Key Words: BRAF mutation, RET/PTC rearrangement, Thyroid, Adrenal, Genetics

\section{INTRODUCTION}

Oncogenesis is a complex process with a variety of players involved. The mechanisms underlying this process in different organ systems have been, to some extent, uncovered. Changes at the molecular level, including DNA, RNA and protein changes as well as alterations in small RNA molecules contribute to this complex process. Furthermore external, nutritional, environmental factors, also contribute to carcinogenesis in many organ systems (1).

Tumors in general are subcategorized according to one fundamental feature into either being sporadic or hereditary. In the sporadic tumors the driving changes occur in terminally differentiated cells whereas in hereditary tumors the genetic changes are inherited at the germline level. Sporadic tumors have more complex pathways involved in tumorigenesis as compared to hereditary tumors. The most important contributors of carcinogenesis are tumor associated genes; i.e. tumor suppressor genes and oncogenes. In each normal cell, there are 2 copies of tumor suppressor genes, one inherited from each parent. During tumorigenesis, an inactivating mutation occurs in one copy of the tumor suppressor gene. This usually is called the "first hit". The first hit can be a sporadic event or can be inherited as is the case in cancer syndromes. The loss of function requires silencing of both copies. Proto-oncogenes are nonmutated genes, which stimulate carcinogenesis when mutated. Overexpression or activation can be achieved only with one mutated copy of the gene as opposed to tumor suppressor genes (1).

(Turk Patoloji Derg 2015, 31(Suppl):181-188)

Received : 09.06.2015 Accepted : 17.06.2015
Detection of mutation in a tumor suppressor gene can be achieved by loss of heterozygosity analysis. When a mutation occurs in an oncogene, the protein product is usually overexpressed which enables detection either by immunohistochemistry or by molecular techniques which measure mRNA levels $(1,2)$.

\section{THYROID NEOPLASMS}

Thyroid carcinoma is rare among overall human malignancies; however it is the most common endocrine neoplasm comprising approximately $90 \%$ of all endocrine neoplasms $(3,4)$. Tumors arising from follicular epithelial cells exhibit a wide range of morphologic and behavioral features which have made the attempts to classify these tumors very challenging over the past 50 years. Molecular genetics has made significant advances in this area that indicate the need for a simplified classification of these common neoplasms. Most of the thyroid tumors, originate from the thyroid follicular epithelium (5) . Papillary thyroid carcinoma (PTC) is the most common $(\sim 80 \%)$ of these, followed by follicular thyroid carcinoma (FTC) $(\sim 15 \%)$. Various genetic alterations in thyroid cancer have been unrevealed through recent molecular research, which have also been translated into clinical practice. The majority of genetic alterations observed in PTC and FTC are either point mutations (BRAF and RAS) or rearrangements (RET/ $P T C$ and PAX8/PPAR $)(5,6)$. Point mutations of the $B R A F$ gene are the most common molecular alterations observed in PTC. Among the BRAF mutations occurred in PTC the most common mutation involves nucleotide

Correspondence: Gaye GÜLER TEZEL

Hacettepe Üniversitesi Tip Fakültesi,

Patoloji Anabilim Dalı, ANKARA, TURKEY

E-mail: gayejp@hacettepe.edu.tr Phone: +90 3123051555 
1799 , which results in a valine-to-glutamine substitution. These alterations are observed in $40-45 \%$ of all PTCs. These mutations lead to the constitutive activation of BRAF kinase. Constitutively activated BRAF kinase, in return, stimulates the MAPK pathway which plays a role in thyroid carcinogenesis (7). BRAF ${ }^{\mathrm{V} 600 \mathrm{E}}$ mutation has been identified in neither follicular carcinomas nor benign entities, suggesting a specific role of this mutation for PTC. Hence, molecular testing for $B R A F^{\mathrm{V} 600 \mathrm{E}}$ mutation increases the diagnostic accuracy of cytological preparations of thyroid nodules $(6,8)$. One major drawback of $B R A F$ mutation analysis in PTC is that BRAF mutation is typically detected in PTC with classical morphology and the tall cell variant. The rate of BRAF mutation is however low (10$15 \%)$ in the follicular variant of PTC, which creates the major diagnostic challenge in fine needle aspiration (FNA) cytology evaluation (Figures 1,2). Although controversial, $B R A F^{\mathrm{V} 600 \mathrm{E}}$ has also been reported to be associated with parameters indicating aggressive tumor biology. Among these are tumor presentation at advanced stages, local extension of the tumor as well as metastatic disease at the time of diagnosis, which adds a prognostic utility to this mutation. Extrathyroidal extension has been shown to be associated with $B R A F^{\mathrm{V} 600 \mathrm{E}}$ mutations in PTC which are less than $2 \mathrm{~cm}$ in size (pT1) as well $(7,9-12)$. The K601E point mutation, small in-frame insertions or deletions around codon 600, and $A K A P 9 / B R A F$ rearrangement, are the other rare $B R A F$ mutation observed in $\mathrm{PTC}(13,14)$.

The RET gene is first identified in 1985 by Takahashi as novel human transforming gene which is located on chromosome 10q11.2 (15). It encodes RET protein receptor tyrosine kinase which is expressed at high levels in thyroid parafollicular (C cells) cells. RET proto-oncogene can be activated through RET/PTC chromosomal rearrangement in follicular cells, which in return leads to the activation of MAPK signaling pathway (3). The majority of known $R E T$ rearrangements fuses the tyrosine kinase domain of RET to the 5' portion of different genes. RET/PTC1 and RET/PTC3 are the most commonly observed RET/PTC rearrangements. RET/PTC1 rearrangement is found in 60-70\% of all RET/PTC-positive cases, whereas RET/PTC3 is present in $20-30 \%(16-19)$. RET/PTC1 rearrangement is

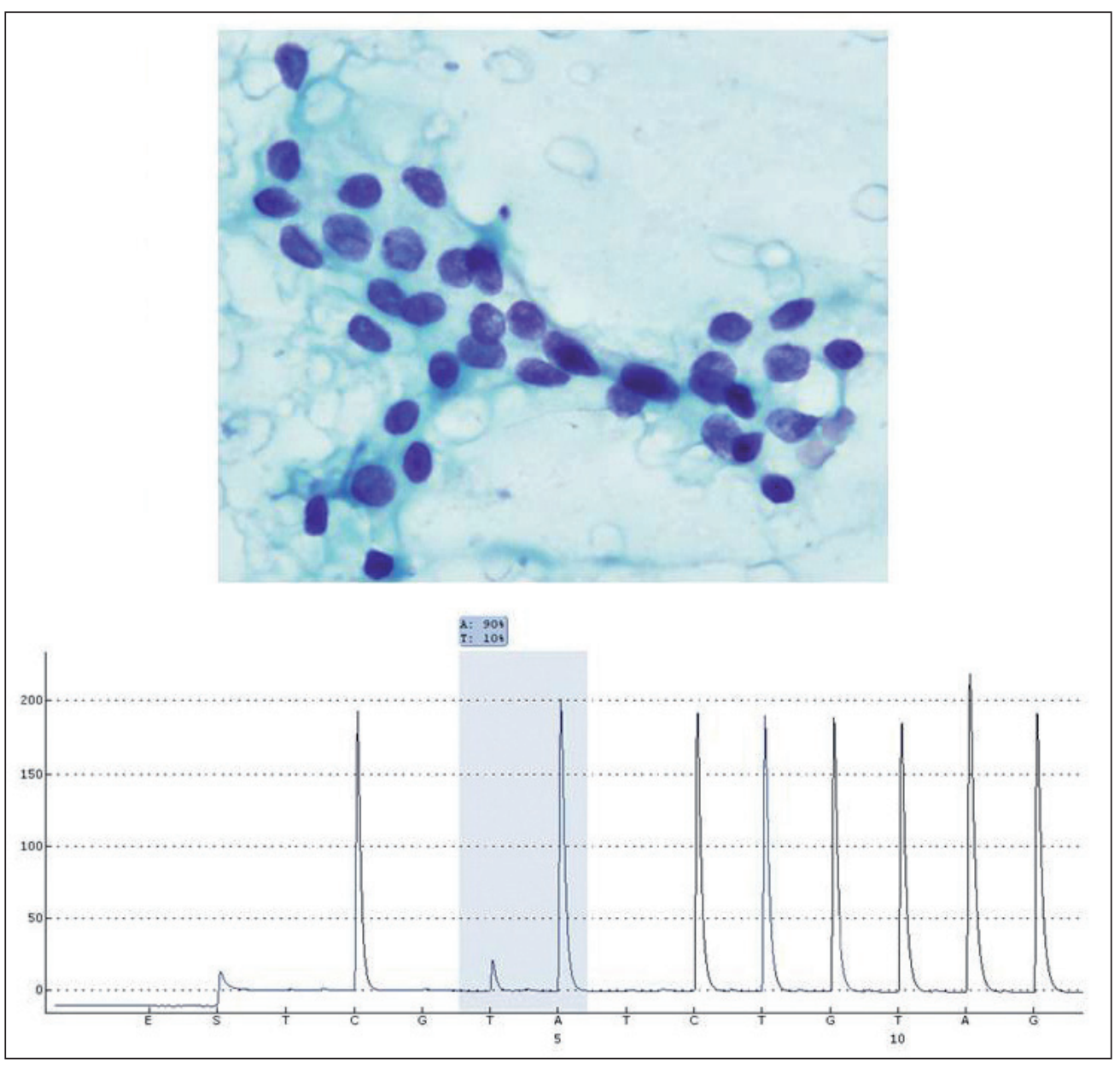

Figure 1: Detection of BRAF mutation. This case of atypia of undetermined significance (AUS) (top) was positive for BRAF codon 600 mutation (V600E) by pyrosequencing analysis (bottom). 
generally associated with classic variant of PTC, papillary growth, microcarcinomas, and benign behavior (2) (Figure 3 ). On the other hand, RET/PTC3 is associated with the solid variant of PTC, radiation associated tumors, and tumor aggressiveness. When appropriate techniques are used, detection of RET/PTC rearrangement is reported to

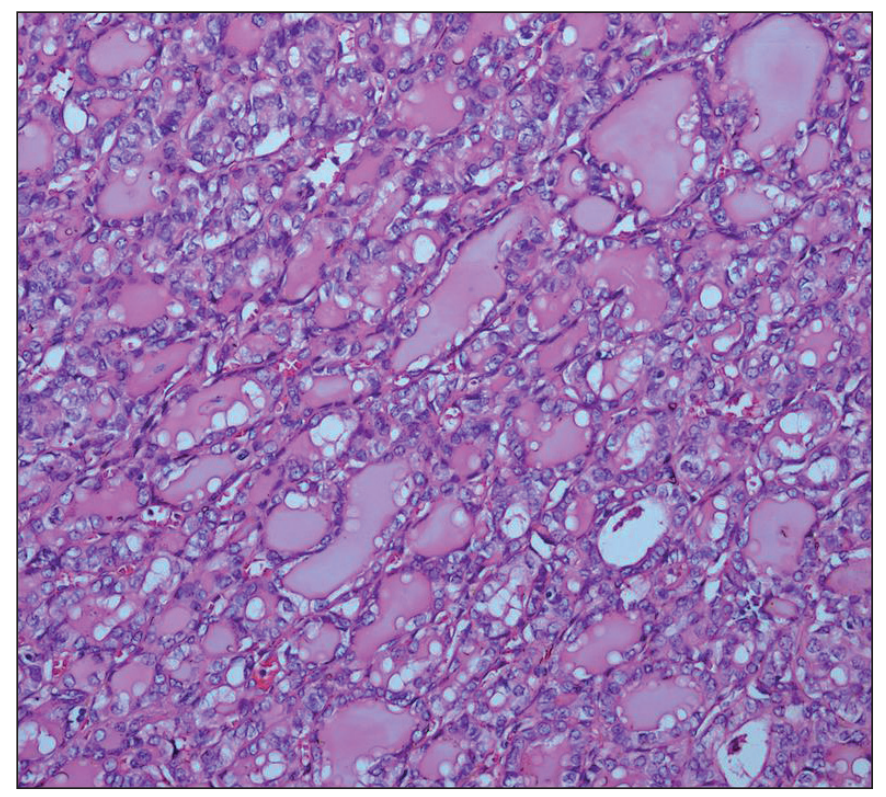

Figure 2: The diagnosis of papillary thyroid carcinoma was histopathologically confirmed at pathological examination. be highly specific for PTC. Depending on the sample type, different detection techniques can be used. For samples such as FNA materials, fresh or snap -frozen tissue samples reverse transcriptase PCR can be the method of choice, whereas for formalin-fixed paraffin-embedded tissue samples fluorescence in situ hybridization is a better choice. RET/PTC-positive PTC typically present at a younger age, shows classic papillary morphology, and tends to metastasize to lymph nodes (10). RET/PTC rearrangements have also diagnostic utility for PTC in FNA samples since detection of clonal RET/PTC supports the diagnosis of PTC. This is especially useful for inadequate cytological preparations and for samples which have indeterminate cytology $(20,21)$. RET is reported to be overexpressed in medullary thyroid carcinoma (MTC) as well owing to the observation of RET protooncogene activation through. germline mutations resulting in aberrant activation of the RET receptors in MEN2A, MEN2B, and familial MTC (3).

RAS gene family, which includes HRAS, KRAS, and $N R A S$, encodes intracellular G-proteins, leading to signal propagation from receptor tyrosine kinases and G-coupled receptors through different intracellular signaling pathways. Hence, mutational activation of $R A S$ proto-oncogenes results in the activation of MAPK pathway. The NRAS codon 61 and HRAS codon 61 mutations are frequently observed in thyroid tumors, contrary to the frequent detection of

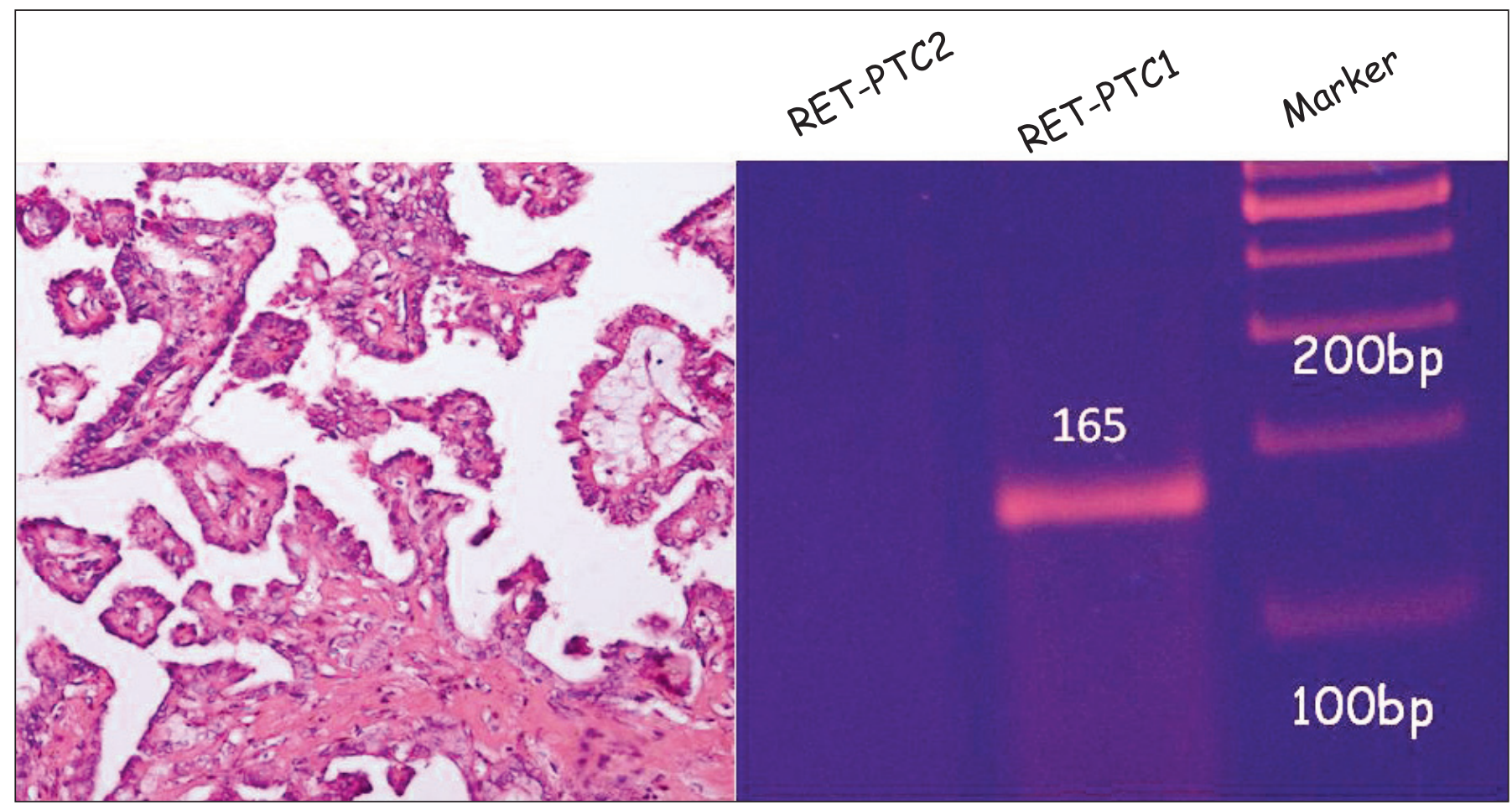

Figure 3: Detection of RET/PTC rearrangement in a classic papillary carcinoma. 
KRAS codon 12/13 mutations in most other types. The frequency of $R A S$ mutations is higher in the follicular types as well as the poorly differentiated and anaplastic thyroid carcinomas. The frequency of RAS mutations in classical FTC are reported to be $40-50 \%$, whereas the detection rate is around $20-40 \%$ in follicular adenomas (22-24). The majority of RAS mutations observed in PTC (10-20\%) are detected in the follicular variant of this tumor (25) (Figure 4). It is also accepted that hyperplastic nodules showing clonal RAS mutations represent neoplasms and therefore should be classified as follicular adenomas.

The $\mathrm{t}(2 ; 3)(\mathrm{q} 13 ; \mathrm{p} 25)$ translocation results in PAX8/PPAR $\gamma$ rearrangement (3). This rearrangement is detected in FTC with conventional histomorphology $(30-40 \%)$ and to a lesser extent in oncocytic variants $(26,27)$. PAX8/ $P P A R \gamma$-positive follicular carcinomas show certain clinicopathological features, i.e. younger age at presentation, smaller size, and more frequent vascular invasion. A small portion of follicular adenomas and follicular variant PTC also show this rearrangement $(27,28)$. Furthermore, it has been reported that follicular adenomas showing this rearrangement demonstrate similar immunohistochemical profile with their malignant counterparts, which indicates that these lesions are probably early lesions of FTCs (29). The observation that Hurthle cell (oncocytic) carcinomas have less frequent PPAR $\gamma$ rearrangements indicates a separate molecular pathway from that of FTC.

In addition to the well known and more common genetic alterations, some very rare mutations are also detected in PTCs. One such mutation involves the TRK rearrangement (30) which is observed in less than $5 \%$ of PTC. Studies using array-based approaches in thyroid malignancies found out changes in gene expression profiles (31) which need further validation studies with larger number of samples (32).
MicroRNAs are noncoding, single-stranded RNA molecules which are 18- to 24-nucleotid long. They are involved in regulation of different cellular processes among which are cell death and proliferation. Differential expression of microRNAs has been reported in many human cancers, including endocrine neoplasms such as PTC, anaplastic thyroid carcinoma, FTC. Several independent studies suggest that microRNA may not have only functional but a diagnostic role in thyroid carcinoma as well. One such relationship is the reduced expression of c-kit in PTC due to its targeted downregulation by microRNA-221 and -222. Studies performed on cell lines harboring RET/ PTC1 rearrangement revealed significant upregulation of four microRNAs; i.e. microRNA-128a, 128b, 139, and 200a and down-regulation of four other microRNAs; i.e. microRNA-154, 181a, 302b, 302c. Two cell lines harboring $B R A F^{V 600 E}$ point mutation showed significant upregulation of microRNA-200a, -200b and -141 with downregulation of microRNA-127, $-130 \mathrm{a}$ and -144. Since these studies are performed on cell lines and a comparison to actual thyroid carcinoma tissues is not yet well established, it is yet not feasible to use these microRNA abnormalities for diagnostic and/or prognostic purposes (2).

\section{Hereditary Papillary Thyroid Carcinoma}

The familial PTCs are rare (33) and tend to be of the cribriform-morular variant of PTC. This variant of PTC occurs in the setting of familial adenomatous polyposis (FAP) presents predominantly in young women and can be either solitary or multiple. The biological behavior is similar to conventional PTC. The presentation of the cribriform-morular variant of PTC may precede the FAP diagnosis which suggests that these patients should be counseled to be tested for FAP (2).

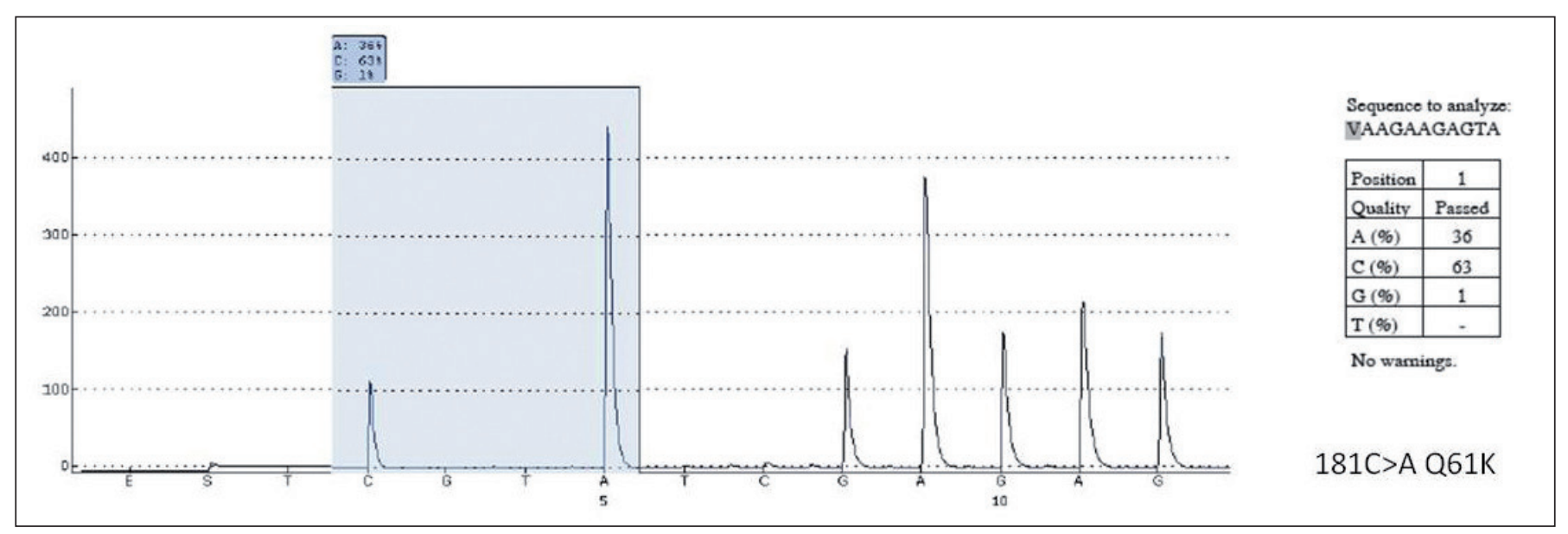

Figure 4: Detection of NRAS mutation at codon 61 by pyrosequencing analysis in a follicular variant papillary thyroid carcinoma. 


\section{ADRENAL CORTEX}

Traditionally, the diagnostic pathology of adrenal cortical diseases includes diffuse lesions and single or multiple nodular conditions. Adrenal cortical diseases are relatively rare but are associated with significant mortality and morbidity. Therefore, it is important to recognize and understand these diseases. In the recent years several new tools have become available for the purpose of better identifying different diseases and in addition to immunophenotyping, molecular markers have led to the definition of more accurate and reproducible categories of adrenal cortical neoplastic diseases.

\section{Genetics of Adrenal Cortical Diseases}

\section{Adrenal Cortical Tumors in Familial Cancer Susceptibility Syndromes}

Even if the majority of adrenal cortical carcinomas arise in a sporadic setting, a minority of cases are associated with familial cancer syndromes, including the autosomal dominant $\mathrm{Li}$-Fraumeni and Beckwith-Wiedemann syndromes and, more rarely, the Gardner syndrome, multiple endocrine neoplasia type 1, neurofibromatosis type 1, and the Carney complex (34). The association of adrenal cortical carcinoma with two conditions that will subsequently be coded as the Li-Fraumeni and hereditary colon cancer syndromes had already been established in the 1980s.

\section{Sporadic Adrenal Cortical Tumors}

\section{Gene Mutations}

Germline alterations of tumor suppressor genes and oncogenes responsible for familial cancer syndromes have also been found as somatic alterations in sporadic adrenal cortical tumors, especially in carcinomas. Losses of the MEN1 gene locus at $11 \mathrm{q} 13$, but very infrequent gene mutations, have been detected in sporadic adrenal tumors $(35,36)$. Somatic mutations of the TP53 gene, as seen in Li-Fraumeni syndrome, as well as p53 protein accumulation can be detected in sporadic tumors. The detection of these changes are considered as signs of malignancy, being virtually absent in adenomas. Activation of the Wnt/ $\beta$-catenin pathway as the result of CTNNB1 mutations has been documented in up to $40 \%$ of carcinomas, but also in a relevant proportion of adenomas $(37,38)$, especially nonsecreting and/or largesize tumors (39). Finally, somatic inactivating mutations or allelic losses of the PRKAR1A locus at 17q22-24, involved in the Carney complex, were also observed in sporadic adrenal cortex lesions (40). However, a significant proportion of adrenal cortical tumors lacks known genetic defects, and therefore, there are several studies ongoing to clarify molecular mechanisms alternative to gene mutations in the pathogenesis of these tumors.

\section{Chromosomal Imbalances}

A number of studies have reported that chromosomal aberrations are more frequent in malignant than in benign and hyperplastic adrenal cortical lesions. Gains, losses, and amplifications can be detected with either comparative genomic hybridization (CGH) or allelotyping techniques. In particular, gains in chromosomes $6 \mathrm{q}, 7 \mathrm{q}, 12 \mathrm{q}$, and $19 \mathrm{p}$, and losses in chromosomes $3,8,10 \mathrm{p}, 16 \mathrm{q}, 17 \mathrm{q}$, and $19 \mathrm{q}$, have been associated with a significantly worse survival of adrenal cortical cancer patients, which were independent of tumor size, tumor weight, and functional status of the tumor $(41,42)$. A strong relationship between tumor size and number of chromosomal aberrations was reported, with no gains or losses detectable in adenomas smaller than $5 \mathrm{~cm}$; conversely, gains on chromosomes 4 and 5 and losses on 2, 11, and 17 were apparently restricted to carcinomas having a size of 7-20 cm. Overall, extensive genomic imbalances were detected in carcinomas using CGH technology. This suggests a complex molecular pathogenesis for the development of sporadic tumors which involves various genetic alterations for transformation and tumor progression $(43,44)$.

\section{MicroRNA Profiling}

Since the differential diagnosis of adenoma versus carcinoma is a challenging one in adrenal cortical lesions, several studies have attempted to find novel markers of malignancy including microRNA analysis. Among the frequently overexpressed or downregulated miR types, miR-483 (in both 3p and 5p isoforms) and miR-195 are those more consistently found overexpressed and downregulated, respectively, both at the tissue and serum levels. However, data concerning the prognostic role of these two miRNAs are controversial (45). miR-210 is another miRNA which was reported to be upregulated by different groups. It is the miRNA most consistently induced under hypoxia, and high levels were found associated with clinicopathological parameters of aggressiveness (necrosis and high Ki-67 proliferation index) and a poorer survival (46).

\section{DNA Methylation Profiling}

The role of DNA hypermethylation in adrenal cortical tumorigenesis has been evaluated in some recent studies. In addition to altered DNA methylation of the $H 19$ promoter and the promotor methylation of TP53, a significant DNA hypermethylation of the RASSF1A promoter in adrenal cortical carcinoma, but not in adenoma, has been described, 
suggesting an epigenetic mechanism for RASSF1A silencing in malignant adrenal cortical tumors. More recently, two clusters of adrenal cortical carcinomas based on $\mathrm{CpG}$ island methylation status, the $\mathrm{CpG}$ island methylator phenotype ("CIMP") and "non-CIMP" were identified, the former associated to a poorer prognosis(45).

\section{PARATHYROID}

Parathyroid pathology which often gives rise to hyperparathyroidism (HPT), can be due to adenoma, hyperplasia or carcinoma. In the vast majority of cases $(80-85 \%)$ HPT is primary and is the result of an adenoma which is a disease of one of the parathyroid glands. The histopathological and molecular discrimination of adenoma (PA) versus carcinoma (PT-CA) can create a real challenge in routine pathology practice. This topic has been discussed in corresponding review article in this special issue.

\section{GASTROINTESTINAL TRACT}

\section{Gastrointestinal Neuroendocrine Tumors (GI NET)}

Gastrointestinal neuroendocrine tumors (GI NETs) are a group of tumors which arise from diffuse neuroendocrine system cells. Common to this group of tumors is the expression of neuroendocrine markers and production of certain peptide or amine hormones.

\section{Molecular Genetics}

Since GI NETs are a heterogenous group of tumors, the molecular mechanisms involved in these tumors are also heterogenous and poorly understood. Several studies have shown that genes common in many other tumor types are not involved in the pathogenesis of GI NETs which is also the case for pancreatic endocrine neoplasms (PEN). Among the limited number of genes involved in GI NET development, mutations of MEN1 gene have often been observed in association with endocrine tumors of the stomach, duodenum, and pancreas (47). Mutation of the NF1 gene, on the other hand, leads to an increased risk for periampullary tumors (48). Several studies have revealed frequent alterations of chromosome 18q, which contains important genes such as Smad2, Smad4 and DCC genes. Another important observation is the detection of $\mathrm{LOH}$ in $\mathrm{X}$-chromosome or $17 \mathrm{q} 13$ only in malignant NETs. The mutations of Reg1 alpha gene is associated with histamine producing ECL cell tumors in the setting of hypergastrinemia (49).

One of the most common genetic alterations observed in PENs, following MEN1 mutations, is the LOH on chromosome $3 \mathrm{p}$, which has been detected in around 30\% of the cases. Studies have failed to demonstrate significant roles for tumor suppressor genes or oncogenes in PENs which are commonly altered in other tumor types. Arraybased techniques revealed alterations of several different group of genes which may play an important role not only in the pathogenesis but in the prognosis of PENs as well (50-53).

Among these are oncogenes, growth factor -related genes, cell adhesion and migration molecules, potential biomarkers, therapeutic targets, cell cycle check point genes, transcription factors and apoptosis -related genes (54-56). However one major drawback of these observations is the low level of concordance among the published data, which requires further investigations in larger PEN sample groups.

\section{ACKNOWLEDGEMENTS}

We thank Arda Gunay and Aybuke Kabaoglu, MSc for their technical assistance and Sehbal Arslankoz, MD for her valuable help during preparation of the manuscript.

\section{CONFLICT OF INTEREST}

The authors have declared no conflict of interest.

\section{REFERENCES}

1. Hoppner W. Clinical impact of molecular diagnostics in endocrinology. Polymorphisms, mutations and DNA technologies. Horm Res. 2002;58 Suppl 3:7-15.

2. JL H. Molecular pathology of the endocrine system In: Hunt JL CP, editor. Molecular oncogenesis. New York:Springer Science+Bussiness Media; 2010. 3-8.

3. Bhaijee F, Nikiforov YE. Molecular analysis of thyroid tumors. Endocr Pathol. 2011;22:126-33.

4. Prasad NB, Kowalski J, Tsai HL, Talbot K, Somervell H, Kouniavsky G, Wang Y, Dackiw AP, Westra WH, Clark DP, Libutti SK, Umbricht CB, Zeiger MA. Three-gene molecular diagnostic model for thyroid cancer. Thyroid. 2012;22:275-84.

5. Nikiforov YE. Molecular diagnostics of thyroid tumors. Arch Pathol Lab Med. 2011;135:569-77.

6. Kouniavsky G, Zeiger MA. The quest for diagnostic molecular markers for thyroid nodules with indeterminate or suspicious cytology. J Surg Oncol. 2012;105:438-43.

7. Trovisco V, Soares P, Preto A, de Castro IV, Lima J, Castro P, Maximo V, Botelho T, Moreira S, Meireles AM, Magalhaes J, Abrosimov A, Cameselle-Teijeiro J, Sobrinho-Simoes M. Type and prevalence of BRAF mutations are closely associated with papillary thyroid carcinoma histotype and patients' age but not with tumour aggressiveness. Virchows Arch. 2005;446:589-95.

8. Melck AL, Yip L. Predicting malignancy in thyroid nodules: Molecular advances. Head Neck. 2012;34:1355-61.

9. Powell N, Jeremiah S, Morishita M, Dudley E, Bethel J, Bogdanova T, Tronko M, Thomas G. Frequency of BRAF T1796A mutation in papillary thyroid carcinoma relates to age of patient at diagnosis and not to radiation exposure. J Pathol. 2005;205:558-64. 
10. Adeniran AJ, Zhu Z, Gandhi M, Steward DL, Fidler JP, Giordano TJ, Biddinger PW, Nikiforov YE. Correlation between genetic alterations and microscopic features, clinical manifestations, and prognostic characteristics of thyroid papillary carcinomas. Am J Surg Pathol. 2006;30:216-22.

11. Kim TY, Kim WB, Rhee YS, Song JY, Kim JM, Gong G, Lee S, Kim SY, Kim SC, Hong SJ, Shong YK. The BRAF mutation is useful for prediction of clinical recurrence in low-risk patients with conventional papillary thyroid carcinoma. Clin Endocrinol (Oxf). 2006;65:364-8

12. Di Cristofaro J, Marcy M, Vasko V, Sebag F, Fakhry N, WynfordThomas D, De Micco C. Molecular genetic study comparing follicular variant versus classic papillary thyroid carcinomas: Association of N-ras mutation in codon 61 with follicular variant. Hum Pathol. 2006;37:824-30.

13. Ciampi R, Knauf JA, Kerler R, Gandhi M, Zhu Z, Nikiforova MN, Rabes HM, Fagin JA, Nikiforov YE. Oncogenic AKAP9-BRAF fusion is a novel mechanism of MAPK pathway activation in thyroid cancer. J Clin Invest. 2005;115:94-101.

14. Moretti S, Macchiarulo A, De Falco V, Avenia N, Barbi F, Carta C, Cavaliere A, Melillo RM, Passeri L, Santeusanio F, Tartaglia M, Santoro M, Puxeddu E. Biochemical and molecular characterization of the novel BRAF(V599Ins) mutation detected in a classic papillary thyroid carcinoma. Oncogene. 2006;25:423540 .

15. Takahashi M, Ritz J, Cooper GM. Activation of a novel human transforming gene, ret, by DNA rearrangement. Cell. 1985;42:5818 .

16. Santoro M, Chiappetta G, Cerrato A, Salvatore D, Zhang L, Manzo G, Picone A, Portella G, Santelli G, Vecchio G, Fusco A. Development of thyroid papillary carcinomas secondary to tissue-specific expression of the RET/PTC1 oncogene in transgenic mice. Oncogene. 1996;12:1821-6.

17. Powell DJ, Jr., Russell J, Nibu K, Li G, Rhee E, Liao M, Goldstein M, Keane WM, Santoro M, Fusco A, Rothstein JL. The RET/ PTC3 oncogene: Metastatic solid-type papillary carcinomas in murine thyroids. Cancer Res. 1998;58:5523-8.

18. Bongarzone I, Vigneri P, Mariani L, Collini P, Pilotti S, Pierotti MA. RET/NTRK1 rearrangements in thyroid gland tumors of the papillary carcinoma family: Correlation with clinicopathological features. Clin Cancer Res. 1998;4:223-8.

19. Tallini G, Santoro M, Helie M, Carlomagno F, Salvatore G, Chiappetta G, Carcangiu ML, Fusco A. RET/PTC oncogene activation defines a subset of papillary thyroid carcinomas lacking evidence of progression to poorly differentiated or undifferentiated tumor phenotypes. Clin Cancer Res. 1998;4:28794.

20. Salvatore G, Giannini R, Faviana P, Caleo A, Migliaccio I, Fagin JA, Nikiforov YE, Troncone G, Palombini L, Basolo F, Santoro M. Analysis of BRAF point mutation and RET/PTC rearrangement refines the fine-needle aspiration diagnosis of papillary thyroid carcinoma. J Clin Endocrinol Metab. 2004;89:5175-80.
21. Pizzolanti G, Russo L, Richiusa P, Bronte V, Nuara RB, Rodolico V, Amato MC, Smeraldi L, Sisto PS, Nucera M, Bommarito A, Citarrella R, Lo Coco R, Cabibi D, Lo Coco A, Frasca F, Gulotta G, Latteri MA, Modica G, Galluzzo A, Giordano C. Fine-needle aspiration molecular analysis for the diagnosis of papillary thyroid carcinoma through BRAF V600E mutation and RET/ PTC rearrangement. Thyroid. 2007;17:1109-15.

22. Suarez HG, du Villard JA, Severino M, Caillou B, Schlumberger M, Tubiana M, Parmentier C, Monier R. Presence of mutations in all three ras genes in human thyroid tumors. Oncogene. 1990;5:565-70.

23. Esapa CT, Johnson SJ, Kendall-Taylor P, Lennard TW, Harris PE. Prevalence of Ras mutations in thyroid neoplasia. Clin Endocrinol (Oxf). 1999;50:529-35.

24. Motoi N, Sakamoto A, Yamochi T, Horiuchi H, Motoi T, Machinami R. Role of ras mutation in the progression of thyroid carcinoma of follicular epithelial origin. Pathol Res Pract. 2000;196:1-7.

25. Basolo F, Pisaturo F, Pollina LE, Fontanini G, Elisei R, Molinaro E, Iacconi P, Miccoli P, Pacini F. N-ras mutation in poorly differentiated thyroid carcinomas: Correlation with bone metastases and inverse correlation to thyroglobulin expression. Thyroid. 2000;10:19-23.

26. Dwight T, Thoppe SR, Foukakis T, Lui WO, Wallin G, Hoog A, Frisk $\mathrm{T}$, Larsson C, Zedenius J. Involvement of the PAX8/peroxisome proliferator-activated receptor gamma rearrangement in follicular thyroid tumors.J Clin Endocrinol Metab. 2003;88:4440-5.

27. French CA, Alexander EK, Cibas ES, Nose V, Laguette J, Faquin W, Garber J, Moore F Jr, Fletcher JA, Larsen PR, Kroll TG. Genetic and biological subgroups of low-stage follicular thyroid cancer. Am J Pathol. 2003;162:1053-60

28. Guney G, Tezel GG, Kosemehmetoglu K, Yilmaz E, Balci S, Ersoy R, Cakir B, Guler G. Molecular features of follicular variant papillary carcinoma of thyroid: Comparison of areas with or without classical nuclear features. Endocr Pathol. 2014;25:241-7.

29. Nikiforova MN, Lynch RA, Biddinger PW, Alexander EK, Dorn GW, 2nd, Tallini G, Kroll TG, Nikiforov YE. RAS point mutations and PAX8-PPAR gamma rearrangement in thyroid tumors: Evidence for distinct molecular pathways in thyroid follicular carcinoma. J Clin Endocrinol Metab. 2003;88:2318-26.

30. Musholt TJ, Musholt PB, Khaladj N, Schulz D, Scheumann GF, Klempnauer J. Prognostic significance of RET and NTRK1 rearrangements in sporadic papillary thyroid carcinoma. Surgery. 2000;128:984-93.

31. Chevillard S, Ugolin N, Vielh P, Ory K, Levalois C, Elliott D, Clayman GL, El-Naggar AK. Gene expression profiling of differentiated thyroid neoplasms: Diagnostic and clinical implications. Clin Cancer Res. 2004;10:6586-97.

32. Chudova D, Wilde JI, Wang ET, Wang H, Rabbee N, Egidio CM, Reynolds J, Tom E, Pagan M, Rigl CT, Friedman L, Wang CC, Lanman RB, Zeiger M, Kebebew E, Rosai J, Fellegara G, LiVolsi VA, Kennedy GC. Molecular classification of thyroid nodules using high-dimensionality genomic data. J Clin Endocrinol Metab. 2010;95:5296-304. 
33. Alsanea O, Clark OH. Familial thyroid cancer. Curr Opin Oncol. 2001;13:44-51.

34. Else T. Association of adrenocortical carcinoma with familial cancer susceptibility syndromes. Mol Cell Endocrinol. 2012;351:66-70.

35. Heppner C, Reincke M, Agarwal SK, Mora P, Allolio B, Burns AL, Spiegel AM, Marx SJ. MEN1 gene analysis in sporadic adrenocortical neoplasms.J Clin Endocrinol Metab. 1999;84:2169.

36. Schulte KM, Mengel M, Heinze M, Simon D, Scheuring S, Kohrer $\mathrm{K}$, Roher HD. Complete sequencing and messenger ribonucleic acid expression analysis of the MEN I gene in adrenal cancer. J Clin Endocrinol Metab. 2000;85:441-8.

37. Tissier F, Cavard C, Groussin L, Perlemoine K, Fumey G, Hagnere AM, Rene-Corail F, Jullian E, Gicquel C, Bertagna X, VacherLavenu MC, Perret C, Bertherat J. Mutations of beta-catenin in adrenocortical tumors: Activation of the Wnt signaling pathway is a frequent event in both benign and malignant adrenocortical tumors. Cancer Res. 2005;65:7622-7.

38. Berthon A, Martinez A, Bertherat J, Val P. Wnt/beta-catenin signalling in adrenal physiology and tumour development. Mol Cell Endocrinol. 2012;351:87-95.

39. Bonnet S, Gaujoux S, Launay P, Baudry C, Chokri I, Ragazzon B, Libe R, Rene-Corail F, Audebourg A, Vacher-Lavenu MC, Groussin L, Bertagna X, Dousset B, Bertherat J, Tissier F. Wnt/ beta-catenin pathway activation in adrenocortical adenomas is frequently due to somatic CTNNB1-activating mutations, which are associated with larger and nonsecreting tumors: A study in cortisol-secreting and -nonsecreting tumors. J Clin Endocrinol Metab. 2011;96:E419-26.

40. Yu B, Ragazzon B, Rizk-Rabin M, Bertherat J. Protein kinase A alterations in endocrine tumors. Horm Metab Res. 2012;44:7418.

41. Stephan EA, Chung TH, Grant CS, Kim S, Von Hoff DD, Trent JM, Demeure MJ. Adrenocortical carcinoma survival rates correlated to genomic copy number variants. Mol Cancer Ther. 2008;7:425-31.

42. Cibas ES, Medeiros LJ, Weinberg DS, Gelb AB, Weiss LM. Cellular DNA profiles of benign and malignant adrenocortical tumors. Am J Surg Pathol. 1990;14:948-55.

43. Letouze E, Rosati R, Komechen H, Doghman M, Marisa L, Fluck C, de Krijger RR, van Noesel MM, Mas JC, Pianovski MA, Zambetti GP, Figueiredo BC, Lalli E. SNP array profiling of childhood adrenocortical tumors reveals distinct pathways of tumorigenesis and highlights candidate driver genes. J Clin Endocrinol Metab. 2012;97:E1284-93.

44. Kjellman M, Kallioniemi OP, Karhu R, Hoog A, Farnebo LO, Auer G, Larsson C, Backdahl M. Genetic aberrations in adrenocortical tumors detected using comparative genomic hybridization correlate with tumor size and malignancy. Cancer Res. 1996;56:4219-23.

45. Barreau O, Assie G, Wilmot-Roussel H, Ragazzon B, Baudry C, Perlemoine K, Rene-Corail F, Bertagna X, Dousset B, Hamzaoui N, Tissier F, de Reynies A, Bertherat J. Identification of a CpG island methylator phenotype in adrenocortical carcinomas. J Clin Endocrinol Metab. 2013;98:E174-84.
46. Duregon E, Rapa I, Votta A, Giorcelli J, Daffara F, Terzolo M, Scagliotti GV, Volante M, Papotti M. MicroRNA expression patterns in adrenocortical carcinoma variants and clinical pathologic correlations. Hum Pathol. 2014;45:1555-62.

47. Pipeleers-Marichal M, Somers G, Willems G, Foulis A, Imrie C, Bishop AE, Polak JM, Hacki WH, Stamm B, Heitz PU. Gastrinomas in the duodenums of patients with multiple endocrine neoplasia type 1 and the Zollinger-Ellison syndrome. N Engl J Med. 1990;322:723-7.

48. Klein A, Clemens J, Cameron J. Periampullary neoplasms in von Recklinghausen's disease.Surgery. 1989;106:815-9.

49. Higham AD, Bishop LA, Dimaline R, Blackmore CG, Dobbins AC, Varro A, Thompson DG, Dockray GJ. Mutations of RegIalpha are associated with enterochromaffin-like cell tumor development in patients with hypergastrinemia. Gastroenterology. 1999;116:1310-8.

50. Gortz B, Roth J, Krahenmann A, de Krijger RR, Muletta-Feurer S, Rutimann K, Saremaslani P, Speel EJ, Heitz PU, Komminoth P. Mutations and allelic deletions of the MEN1 gene are associated with a subset of sporadic endocrine pancreatic and neuroendocrine tumors and not restricted to foregut neoplasms. Am J Pathol. 1999;154:429-36.

51. Gumbs AA, Moore PS, Falconi M, Bassi C, Beghelli S, Modlin I, Scarpa A. Review of the clinical, histological, and molecular aspects of pancreatic endocrine neoplasms. J Surg Oncol. 2002;81:45-53; discussion 54.

52. Jonkers YM, Claessen SM, Veltman JA, Geurts van Kessel A, Dinjens WN, Skogseid B, Ramaekers FC, Speel EJ. Molecular parameters associated with insulinoma progression: Chromosomal instability versus p53 and CK19 status. Cytogenet Genome Res. 2006;115:289-97.

53. Proca DM, Frankel WL. Pancreatic endocrine tumors-c-erb B2 (Her-2/neu), bcl-2, and p-53 immunohistochemical testing and their value in assessing prognosis. Appl Immunohistochem Mol Morphol. 2008;16:44-7.

54. Maitra A, Hansel DE, Argani P, Ashfaq R, Rahman A, Naji A, Deng S, Geradts J, Hawthorne L, House MG, Yeo CJ. Global expression analysis of well-differentiated pancreatic endocrine neoplasms using oligonucleotide microarrays. Clin Cancer Res. 2003;9:5988-95.

55. Bloomston M, Durkin A, Yang I, Rojiani M, Rosemurgy AS, Enkmann S, Yeatman TJ, Zervos EE. Identification of molecular markers specific for pancreatic neuroendocrine tumors by genetic profiling of core biopsies. Ann Surg Oncol. 2004;11:413-9.

56. Capurso G, Lattimore S, Crnogorac-Jurcevic T, Panzuto F, Milione M, Bhakta V, Campanini N, Swift SM, Bordi C, Delle Fave G, Lemoine NR. Gene expression profiles of progressive pancreatic endocrine tumours and their liver metastases reveal potential novel markers and therapeutic targets. Endocr Relat Cancer. 2006;13:541-58. 